\title{
Türkiye'de Sağır ve İ̧̧itme Engelli Çocuklar için Ayrıntılı Altyazı Çevirisi Hakkında Bir Araştırma: Uygulamada Sadeleştirme ${ }^{1}$
}

\author{
SDH for Child Audiences in Turkey: Practice of Plain Subtitling
}

Araştırma/Research

\author{
Sinem SANCAKTAROĞLU BOZKURT*, Ayşe Şirin OKYAYUZ** \\ *Dr. Öğr. Üyesi, Hacettepe Üniversitesi, Edebiyat Fakültesi, Mütercim Tercümanlık Bölümü, \\ ssbozkurt@hacettepe.edu.tr, ORCID ID: orcid.org/0000-0003-0376-0358 \\ **Doç. Dr., Hacettepe Üniversitesi, Edebiyat Fakültesi, Mütercim Tercümanlık Bölümü, \\ sirinokyayuz@hacettepe.edu.tr, ORCID ID: orcid.org/0000-0001-7512-2764
}

\section{ÖZET}

Çalışma, Türkiye'de yaşanan son toplumsal gelişmeler ve görsel-işitsel çevirideki son açılımlar ışığında, Sesli Betimleme Derneği (SEBEDER) tarafından 25 Ağustos-09 Ekim 2020 tarihleri arasında yürütülen ve tamamlanan 'Sağır, İşitme Engelli ve Görme Engelli Çocukların Televizyon Programlarına Engelsiz Erişimi Projesi'nin ayrıntılı altyazı bileşeninde elde edilen çıktılardan hareketle hazırlanmıştır. Proje kapsamında tamamlanan, çeviri ve çevirmen kılavuzunun bir bölümü bu çalışmanın odağını oluşturmaktadır. Söz konusu kılavuz çocuk programlarında ayrıntılı altyazı çevirisi uygulamalarını düzenlemek ve kalite yönetimini sağlamak amacıyla hazırlanmıştır. Çalışmanın ilk bölümünde ayrıntılı altyazı çevirisi ve çocuklar için altyazı çevirisi hakkında bilgi verilmiştir. İkinci bölümde ise yukarıda sözü edilen proje özetlenerek paydaşları ve proje döngüsündeki süreçler anlatılmıştır. Daha sonra ise, çalışmanın ana konusu olan çocuklar için ayrıntılı altyazı çevirisinde benimsenmesi tavsiye edilen yaklaşım, yöntem ve uygulama açıklanmıştır. Projenin önemli bir kısmını oluşturan kılavuzda yer alan ayrıntılı altyazıda sadeleştirme ile ilgili bölüme atıfla $\mathrm{S} /$ sağır ve işitme engelli çocuklar için ayrıntılı altyazı uygulamalarına ilişkin bilgi paylaşılmış, $\mathrm{S} /$ sağır ve işitme engelli çocuklar hedeflenerek yapılan ayrıntılı altyazı uygulamalarında uygulanabilecek çeviri stratejileri ve sadeleştirme ilkeleri örneklendirilerek anlatılmıştır. Sonuç bölümünde ise projenin sonuçlarıyla birlikte, Türkiye'de

\footnotetext{
${ }^{1}$ Bu çalışma, Sesli Betimleme Derneği (SEBEDER) tarafından 25 Ağustos-09 Ekim 2020 tarihleri arasında yürütülen ve tamamlanan "Sağır, İşitme Engelli ve Görme Engelli Çocukların Televizyon Programlarına Engelsiz Erişimi Projesi" çıktılarına dayanarak hazırlanmıştır.
} 
Türkiye'de Sağır ve İşitme Engelli Çocuklar için Ayrıntılı Altyazı Çevirisi Hakkında Bir Araştırma: Uygulamada Sadeleştirme

görsel-işitsel çeviride yaşanan son gelişmeler ve bu alanda ülkemizde yapılacak çalışmaların çoğalmasının önemine değinilmiştir.

Anahtar Sözcükler: ayrıntılı altyazı çevirisi, S/sağır ve işitme engelli çocuklar, çocuklar için engelsiz erişim

\section{ABSTRACT}

In light of the recent developments in Turkey and the new studies in the AVT sector, the study provides insight into the findings of the subtitling for the D/deaf and Hard of Hearing (SDH) module of a project completed by the Audio Description Association (SEBEDER) in August 25October 9, 2020 entitled 'Project for Accessibility to Television Programs for Blind, D/deaf and Hard of Hearing Children'. The study concentrates on a part of the translator and translation guideline prepared to standardize translation activity and provide quality assurance. The first part of the study provides information about subtitling for the D/deaf and Hard of Hearing and practices for child audiences. The second part entails a summary of the project, including partners and processes. The following section that forms the core of the study details recommendations as regards the approaches, methods, practices, and other features for subtitling for the D/deaf and Hard of Hearing for child audiences. Strategies and examples from practice are provided about the section of the guidelines on plain subtitling for children. The results of the project, the recent developments in the field in Turkey are briefly referred to in the conclusion alongside recommendations for future projects.

Keywords: SDH (subtitling for the D/deaf and Hard-of-Hearing), D/deaf and hard-of-hearing children, media accessibility for children

\section{Giriş}

Çeviri, toplumsal gerçeklerle, teknolojinin gelişimiyle, benimsenen politikalarla, eğitimin yaygınlaşmasıyla, küreselleşmeyle ve daha birçok etmenle evrilen bir uygulamadır. Günümüzde bunun belki de en somut örnekleri hızla gelişen ve değişen medya ve iletişimle bağlantılı olan görsel-işitsel çeviri alanında görülebilir. Türkiye'de görsel-işitsel çevirinin gelişimine bakarak günümüzde gelinen nokta ve gelişmeler daha olgun bir bakış açısıyla değerlendirilebilmektedir.

Sinemanın Türkiye'ye gelişinden başlayarak Türkçeye çevrilen yabancı filmlerin sayısı artmıştır (Türkiye'de sinema tarihi için bkz. Scognamillo, 2014), ancak görselişitsel çeviri alanındaki uygulamaların Türkiye'de televizyonun yaygınlaşmasıyla birlikte arttığı da açıktır. Türkiye ilk olarak 1960'lı yıllarda televizyon ile tanışmış, yıllar içinde televizyona erişim artmıştır. Televizyonun ilk yıllarında yabancı kaynaklı ürünlere ağırlık verilmiş ve bunlar birtakım değerlendirmelerin ardından Türkçe konuşan izleyicilere sunulmuştur. Söz konusu yıllarda Türkiye'nin benimsediği bir dil politikasından bahsedilebilmektedir. Buna ek olarak, ülkenin sosyal gerçekleri (örneğin, okur yazar oranları, ölçünlü Türkçenin yaygınlaştırılması için girişimler vb.) göz önüne alındığında televizyonda Türkçe yayın yapılması beklenen bir durum olarak yorumlanabilir. Sonuç itibariyle, Türkiye o yıllardan itibaren bir dublaj çevirisi ülkesi olarak bilinmiştir (uygulanan çeviri türlerine göre ülke sınıflaması için bkz. Chaume, 2012; Diaz Cintas ve Remael, 2007). 
Türkiye'de tek kanallı dönem boyunca, yabancı dillerde ve kültürlerde üretilen görsel-işitsel ürünlerin dublaj çevirisi yapılmış, altyazı çevirisi ise neredeyse hiç kullanılmamıştır (sözü edilen dönemle ilgili olarak bkz. Çankaya, 1992). 1990’lı yıllardan itibaren özel televizyon kanalları ve dijital platformlar hızla yaygınlaşmış, bu yıllarda farklı dillerdeki görsel-işitsel ürünler altyazı çevirisi ile de iletilmiştir. Yirmi birinci yüzyıldan itibaren ise altyazı çevirisi özellikle gençler arasında tercih edilir olmuştur. Dolayısıyla, söz konusu dönemde Türkiye artık hem altyazı hem de dublaj çevirisi ile yabancı görsel-işitsel ürünlere erişmiştir (söz konusu dönemdeki gelişmelerin ayrıntıları için bkz. Okyayuz \& Kaya, 2017).

Kısaca değindiğimiz bu gelişmelerden yaklaşık on beş yıl sonra ise Türkiye'de yavaş yavaş engelsiz erişime yönelik çeviri türleri gözlenmeye başlanmıştır (engelsiz erişim ve çeviri için bkz. Okyayuz, 2019a). Zaman içerisinde görme engelliler için sesli betimleme yapılmış, Sağır topluluk için görsel-işitsel ürünlere işaret dili çevirisi eklenmiş ve S/sağır ve işitme engelliler için ayrıntılı altyazı çevirisi adı verilen bir altyazı türü uygulanmaya başlanmıştır. Bu uygulama RTÜK'ün de desteğiyle daha fazla kanal tarafından benimsenmiştir (bkz. RTÜK, 2019a, 2019b). Diğer bir deyişle, artık ürünler sadece yabancı dillerden Türkçeye çevrilmekle kalmamış, dil içi çeviri de yapılır olmuştur. Günümüzde hâlen uygulama örnekleri Avrupa veya ABD'deki kadar yaygın olmasa da büyük gelişmeler yaşandığı ortadadır.

Engelsiz erişim için çeviri türlerinin yaygınlaşmasının ardından, engelli alt grupları hedef alan çalışmalar yapılmaya başlanmış; ayrıntılı altyazı çevirisi hem uygulama açısından hem de kuramsal açıdan (ayrıntılı altyazı çevirisi için bkz. Okyayuz, 2019b) farklı çalışmalar ışığında irdelenmiştir. Özellikle de çocuk alıcılar için ayrıntılı altyazı çevirisinin nasıl yapılması gerektiği konusu gündeme gelmiştir. Söz konusu bu çalışmada Türkiye'deki bu son açılımdan söz edilmektedir.

2020 Ağustos ayında başlayıp Ekim ayında tamamlanan S/sağır ve işitme engelli çocukların çocuk programlarına erişimini hedefleyen proje, Türkiye'de yaşanan son toplumsal gelişmelere ve görsel-işitsel çevirideki son açılımlara başarılı bir örnektir. Çalışmanın ilk bölümünde ayrıntılı altyazı çevirisi ve çocuklar için altyazı çevirisi hakkında bilgi verilmiştir. İkinci bölümde ise yukarıda sözü edilen proje özetlenerek paydaşları ve proje döngüsündeki süreçler anlatılmıştır. Daha sonra ise, çalışmanın ana konusu olan çocuklar için ayrıntılı altyazı çevirisinde benimsenmesi tavsiye edilen yaklaşım, yöntem ve uygulamalar açıklanmıştır. Söz konusu bölüm, çocuk programlarında ayrıntılı altyazı çevirisi uygulamalarını düzenlemek ve kalite yönetimini sağlamak için hazırlanan çeviri ve çevirmen kılavuzunun bir bölümüne odaklanmaktadır. Kılavuzda yer alan ayrıntılı altyazıda sadeleştirme ile ilgili bölüme atıfla S/sağır ve işitme engelli çocuklar için ayrıntılı altyazı uygulamalarına ilişkin bilgi paylaşılmaktadır. Sonuç bölümünde ise projenin sonuçlarıyla birlikte Türkiye'de görselişitsel çeviride yaşanan son gelişmelerin önemine değinilmektedir.

\section{Ayrıntılı Altyazı Çevirisi}

Görsel-işitsel çeviri araştırmaları ve eğitimi yirminci yüzyılın sonlarında hız kazanmıştır. $\mathrm{Bu}$ gelişmeyi takiben, S/sağır ve işitme engellilere yönelik olarak dil içi ve diller arası 
Türkiye'de Sağır ve İşitme Engelli Çocuklar için Ayrıntılı Altyazı Çevirisi Hakkında Bir Araştırma: Uygulamada Sadeleştirme

altyazı çevirisi odağında yürütülen araştırmalar yirmi birinci yüzyılın başlarında önem kazanmıştır (Neves, 2008, s. 171). Türkiye'de olduğu gibi birçok ülkede de uygulama, eğitimi ve araştırmayı beklemeden başlamış ve kendi içinde şekillenmiştir (Diaz-Cintas et al., 2010).

S/sağır ve işitme engelliler için altyazı çevirisi (ayrıntılı altyazı çevirisi) kendilerine özgü alımlama gereksinimleri bulunan bir alıc kitlesi için yapılmaktadır. Perego (2016) ayrıntılı altyazı çevirisinin "başarılı bir görsel-işitsel ürün izleme deneyimini, aynı zamanda bilişsel olarak etkin ve eğlendirici" bir şekilde sunması gerektiğini vurgular. Dolayısıyla, ayrıntılı altyazı çevirisi bir ürünü belirli bir kitleye yönelik olarak tasarlamayı gerektirir (ayrıntılı altyazı çevirisi eğitimi ile ilgili olarak bkz. De Higes Andino \& Cerezo Merchan, 2018).

İlk adımda ürünü kullanacak olan kitleyi tanımlamak gerekir. Neves (2008, s. 172), ayrıntılı altyazı türünün üç ana alıcısını birbirinden ayırır. Büyük S harfi ile yazılan Sağır, Sağır topluluğun işaret dilini ana dili olarak kullanan bireyleridir. Küçük $s$ ile yazılan sağır, belli bir süre içinde işitme duyusunu kaybetmiş ve kısmen de olsa sözlü dili kullanabilen veya "bilen" ve kendini duyan toplumun da bir parçası hisseden bireylerdir. İşitme engelli ise duyan toplumun bir parçası olan ve kısmen işitme duyusu olan ve sese (daha az oranda erişebilse de) duyanlar gibi tepki verebilen kitledir. Bu üç alıc kitleye yönelik olarak çeviri yapabilmek için alıcıların profillerini bilmek gerekir. Ayrıntılı altyazının aynı zamanda belli bir yaştan sonra işitme duyusu zayıflayan kişiler, Türkçe yazı dilinde yetkinliğini geliştirmek isteyenler, Türkçeyi yabancı dil olarak öğrenmek isteyenler tarafından da kullanıldığı olur. Ama genelde ayrıntılı altyazı çevirisi bu kitlelere yönelik tasarlanmayacaktır.

Söz konusu çeviri türü (diğer birçok çeviri türü gibi) bir tasarım gerektirdiğinden bu alanda çalışacak kişinin belli bir birikimi olması gerekecektir. Okyayuz (2019b), ayrıntılı altyazı çevirisi yapacak profesyonellerin sahip olması gereken temel beceri ve bilgileri şu şekilde sıralar:

a) Görsel-işitsel ürün kompozisyonunu, özellikle de görsel ve işitsel düzgülerle bütünleşik olarak anlamlanan ürünün içinde sesin yerini ve (her türlü) anlamını bilmek

b) Görsel-işitsel ürünleri, görsel-işitsel çeviri kuramını ve farklı uygulamaları bilmek

c) Görsel-işitsel ürünün farklı düzgülerinin ayrışık ve bütünleşik olarak çözümlemesini yapabilmek

d) Sesi duymak ve anlamlandırmak, bunu yorumlayabilmek, anlatısal değerini bilebilmek, belirginliğini ve ayrıcalığını saptayabilmek için ses bilgisine sahip olmak

e) İşitsel işaretleri çözümleyerek ve anlamlandırarak görsel işaretlere (yazıya) dönüştürebilmek ve görsel olarak (yazıyla) bunu iletebilmek 
f) Çeviride gereksiz fazlalık veya "ekonomik olmayan dil" olarak tanımlanabilecek artıklık, dilsel ve sessel ögelerde ayırıcılık ve belirginlik, yeterlilik, bağlaşıklık ve bağdaşıklık konularına hâkim olmak

g) Hangi ögelerin yeniden dillendirileceğine kanaat getirmek ve bunu yaparken de belli bir algısal profili olan erek alıcının gereksinimlerini göz önünde bulundurmak (Chesterman ve Wagner, 2002, s. 10)

h) Çeviri ediminde zor kararları verebilmek için, çeviri mantığına hâkim ve çevirmen duyarlılığına sahip olmak

i) Çevirinin başarıya ulaşması için kaynakta amaçlananı yorumlayabilmek. (ss. 10-13)

Sağır alıcının Türkçe okuma becerileri veya işitme engelli bireyin okuma hızı ayrıntılı altyazı çevirisinin alımlanıp alımlanmayacağını belirler. Bir üründe altyazı olması alıcının buna erişebileceği anlamına gelmeyebilir. Ayrıca, her ayrıntılı altyazı çevirisi alıcısına uygun olarak erişimi sağlayacak şekilde tasarlanmamış olabilir.

Ayrıntılı altyazı çevirmenleri (kendisi işaret dili bilen bir CODA-Sağır Ebeveyn Çocuğu veya işitsel düzgüye erişebilen bir işitme engelli değilse) ürünlerinin temel alıcısı olan Sağır bireylerle aynı topluluğa mensup değillerdir. Genelde, ayrıntılı altyazı çevirmenleri kendi anadillerinde (Türkçe) dil içi çeviri yaparlar. Ancak, Sağır bireylerin ana iletişim dilleri Türk işaret dilidir; dolayısıyla çevirideki erek dil genelde alıcı kitlenin ana iletişim dili değildir.

Okyayuz (2019b, ss. 21-23), ayrıntılı altyazı çevirisinde tasarımın öneminden söz ederken bu uygulamada dikkate alınması gereken bazı başlıkları sıralar ve bunları açıklar. Bu başlıklar, yazı dili için doğru kaynakların kullanımı; işitsel düzgünün kapsamı; senkron (spotlama) ve timecode (zaman kodu) unsurlarının önemi; sağır ve işitme engellilerin erişimine uygun çeviri yapmanın önemi; yabancı sözcüklerin ve yabancı dillerdeki repliklerin yazımı; çeviri seçimlerini yapabilmek için parametreler ve kısıtların (zamansal ve uzamsal kısıtlar) kapsamı; senaryo ile çalışmanın önemi; editörlük aşamasının önemi; çevirinin anlam birimleri dikkate alınarak yapılması; öznenin önemi; cümle dizilimini (içeriğini) değiştirmenin gerekli olacağı durumların varlığı; sadeleştirme kavramı; şive, birey dil, zamansal dil, karakter söylemi gibi dil değişkelerinin çevirisi; noktalama işaretlerinin kullanımı; karakter adlarının yazımı; tekrarlar; nidalar ve sözlü dilde anlamlanan seslerin aktarılması; sayıların yazımı; şarkılar ve müziklerin aktarımı; repliklerin başına kişi adlarının ve ses bilgilerinin eklenmesi/eklenmemesi; efektlerin ve seslerin yazımı şeklinde özetlenebilir.

Ayrıntılı altyazı çevirmeninin yukarıda listelenen başlıkların her biri için belli parametreler ve kısıtlar çerçevesinde kararlar alması gerekir. Illk parametre ayrıntılı altyazı çevirmeninin "neyi çevirdiği" ile ilgilidir. Ayrıntılı altyazı çevirisinde işitsel düzgü, karakterlerin diyaloglarını ve diğer her türlü ses(ler)i kapsar. Delabastita (1989), çevirmenin bakış açısından düzgüleri şöyle açıklar:

İşitsel olarak sunulan dilsel gösterge: Film boyunca duyulan tüm diyaloglara ek olarak, şarkı sözleri ve karakterlerin ağzından çıkan bütün sesler ve nidalar bu başlık altında derlenebilir. İşitsel olarak sunulan dilsel olmayan gösterge: Enstrümantal müzik ve fondan gelen bütün ses efektleri. Örneğin, kapının 
Türkiye'de Sağır ve İşitme Engelli Çocuklar için Ayrıntılı Altyazı Çevirisi Hakkında Bir Araştırma: Uygulamada Sadeleştirme

çalınması, arabanın fren sesi, bir eğlence mekânında müzik ve insan sesi bu başlık altında örneklenebilir. (s. 199)

Chiaro (2009) ise düzgülerin ayırımını şu şekilde belirtir:

Dilsel olmayan işitsel düzgü: müzik, fon sesi, efektler, ağlama, bağırma, gülme, beden sesleri vb.

Dilsel işitsel düzgü: diyaloglar, şarkılar, şiirler vb.

Dilsel görsel düzgü: tabelalar, yazılı metinler vb.

Dilsel olmayan görsel düzgü: sahne, ışıklandırma, kostümler, mimikler, jestler, hareketler vb. (s. 143)

İki araştırmacının açıklamalarından da anlaşılacağı üzere ayrıntılı altyazı çevirmeni tüm düzgüleri inceleyerek ve bunların hepsini dikkate alarak çeviri yapacaktır.

Buna ek olarak, çevirmen ürünü "nasıl tasarlayacağını” şekillendirmek için bazı sorular sormak zorundadır. Örneğin, "alıcı kitlenin ortalama eğitim düzeyi (okuma düzeyinde algı birikimi) nedir?", "alıcı kitlenin sosyo-ekonomik profili (bilgi düzeyinde algı birikimi) nedir?", "alıcı kitlenin beklentileri nedir?", "alıcı kitlenin bir izleyici alışkanlığı/ayrıntılı altyazı geleneği var mıdır?" gibi sorular sorulmalıdır.

$\mathrm{Bu}$ soruları cevapladıktan sonra çeviriye başlayacak profesyonel, ürünü şekillendirirken kendine daha başka sorular sormak durumunda da kalır. Örneğin, ortak yazı dilinde buluşulup buluşulmadığı konusu önemli bir konudur. Türkiye'de ayrıntılı altyazı çevirisi çalışmalarında "ortak yazı dili" olarak tanımlanan dil, hem sesli düzgüye erişimi olan çevirmenin hem de aynı düzgüye tam ve/ya kısmi erişimi olmayan alıcının (her ikisinin de) anladığı ve kullandığı yazı dilidir.

İkinci bir konu ise, çevirmenin metinlerin görsel ve işitsel düzgülerini hem ayrı ayrı hem de bütünleşik olarak inceleyerek bir altyazı çevirisi ortaya koyup koymadığıdır. Bu olgu, en basit unsurdan en karmaşık unsura kadar çeviriyi etkiler. Örneğin, bir karakterin sahnede görünmemesi durumunda adının repliğinin başına yazılması veya bir karakterin ilk göründüğü anda repliğinin başına adının yazılması çok basit bir kural gibi görünse de, gereksiz ad yazımı, okuma hızını, kullanılan karakter ve satır sayısını olumsuz yönde etkileyecektir. Karakter adlarının yazılmaması ise Sağır kültüre mensup alıcının metni anlamasını zorlaştıracak hatta kimi zaman imkânsızlaştıracaktır (Okyayuz 2019b, s. 33).

Çevirmene verilen bir ayrıntılı altyazı çevirisi kılavuzu bazı konularda çevirmenin kararlar vermesini kolaylaştıracaktır; ancak, çevirideki her sorunun çözümü kılavuzda bulunmayacaktır. Genelde, kılavuzlarda temel kısıtlarla ilgili bilgi verilmektedir. Birinci tür kısıt, uzamsal ve zamansal kısıttır. Sözlü dil (zihinsel algılama süreci açısından) yazı dilinden daha hızı erişilebilen bir düzgüdür. Dolayısıyla, yazılı dile, sözlü dilin algılandığı (erişildiği) hızda erişilemez (bkz. Romero-Fresco, 2009; Remael, 2007). Ayrıca, satır sayısı bellidir (2 satır); bir satırda yer alabilecek karakter sayısı da bellidir (tercihen azami olarak boşluklu 42 karakter x 2 satır). Alandaki çalışmaların bazılarında, satır 
bölümlemesinin alıcıların okuma kalitesini ve hızını etkilemediği ortaya konulurken, başka çalışmalarda anlamsal birimler göz ardı edilerek yapılan bölümlemelerde okuma ve algılama açısından sıkıntılar çıktığı ortaya konulmuştur (bkz. ABC, 2010; BBC, 2018; Doherty \& Kruger, 2018; Media Access Australia, 2012).

İşitsel düzgünün görsel bir düzgüye çevrildiği ayrıntılı altyazı çevirisinde ek bir kısıt daha vardır. Sözlü dilde vurgu, sesletim, tonlama ve benzeri bürünsel unsurlarla ifade edilenler (korunması için metne ekleme yapılmadıkça ve özel bir çaba sarf edilmedikçe) yazılı dilde kaybolacaktır.

Kısıtlara ek olarak çevirmenin olasılıkları bilmesi de önemlidir. Çevirmen seçimleri bir ürünü kaliteli veya kalitesiz kılan unsurlardır. Çevirmen, seçimlerini bilinçli ve tutarlı bir şekilde, erek alıcının alımlamasını sağlamak üzere yapmalıdır. Dolayısıyla, ayrıntılı altyazı çevirmeni seçimlerini yaparken birçok unsuru da dikkate alacak ve sadece işitselin dökümünü altyazıya aktarmayacaktır. Kısıtları dikkate alacaktır (örneğin, satır ve karakter sayısı konusundaki kısıtlar, altyazı karelerine bölmeye ilişkin kısıtları). Alıcının okuma hızını dikkate alacaktır. Altyazıya erişimin azami süreyi aşıp aşmadığını kontrol edecektir. Amaçsız tekrarlar olmamasını sağlayacaktır. Altyazının anlaşılır olmasına dikkat edecektir. Üründeki işitsel yoğunluğu yöneterek altyazıya alıcının algılaması için gerekli olan bilgiyi dâhil edecektir. Bunlara ek olarak, üründeki dil hatalarını giderecektir.

Kısacası, sunulan bilgilerden de anlaşılacağı üzere, ayrıntılı altyazı çevirisi alanı bilmeyen biri için "söyleneni ve duyulanı yazmaktan" ibaretken, işini iyi yapan bir profesyonel için zorlu bir edimdir. Bir de bu uygulama çocuklar için yapıldığında ek birtakım zorlukları beraberinde getirmektedir.

\section{1 Çocuklar için Ayrıntılı Altyazı Çevirisi}

Ayrıntılı altyazı çalışmaları alanı hızla gelişmektedir. Uygulamada çok başarılı olan ülkeler bulunmaktadır. Örneğin, Birleşik Krallıktaki 4 ana yayıncı (BBC, Channel 4, Channel 5, ITV) programlarının yaklaşık \%92.6-\%100'ünde ayrıntılı altyazı seçeneği sunmaktadır (Ofcom, 2013). Hollanda'da programların yaklaşık \%90'ı, Belçika'da da \%95'i ayrıntılı altyazı çevirisiyle sunulmaktadır (EFHOH, 2011).

Günümüzde birçok ülkede yaşanan bu gelişmelere koşut olarak Sağır ve işitme engelli çocuklar için ayrıntılı altyazı yapılması konusu gündeme gelmektedir. Bu konuda Sağır ve işitme engelli çocukların ebeveynleri veya eğitimciler aracılığıyla tamamlanan anket çalışmaları da yapılmaktadır.

Çocuklar için ayrıntılı altyazı çevirisi ile ilgili ilk çalışmalardan biri Baker ve diğerleri (1984) tarafından yapılmıştır. Araştırmacılar ortaöğretimdeki sağır çocukların dil ediniminde altyazı çevirisinin etkinliği üzerine bir çalışma yapmışlardır. Çalışmada söz konusu kitledeki çocukların azami olarak dakikada 60 sözcüğü okuyabildikleri, sadeleştirilmiş dil ve terim kullanımının önemli olduğu, altyazıların "yeni sözcükleri" tanıtmak ve alıcıların sözcük haznelerini genişletmek için bir araç olarak kullanılabileceği ortaya konmuştur. De Linde ve Kay (1999) ise çalışmalarında Sağır ve işitme engelli çocuklar için altyazılarda ortalama 90 kelime/dakika önerisinde 
Türkiye'de Sağır ve İşitme Engelli Çocuklar için Ayrıntılı Altyazı Çevirisi Hakkında Bir Araştırma: Uygulamada Sadeleştirme

bulunmaktadırlar. Gregory ve Sancho-Aldridge (1996) tarafından yapılan bir çalışmada ise alıcı kitleyi oluşturan çocukların profillerinin bilinmesi üzerinde durulmuş ve bu alandaki araştırma boşluklarına değinilmiştir. Paivio ve Lambert (1981) ise çalışmalarında Sağır ve işitme engelli çocuklar için ayrıntılı altyazıların bir eğitim aracı olduğu konusunu ele alıp bu alanda bir kuram ortaya koymuşlardır (ayrıca bkz. Paivio, 1991). Danan (2004), Talaván (2006) gibi araştırmacılar da altyazıların özellikle de ikinci dil edinimi ve dil gelişimi için yararları hakkında çalışmalar yapmışlardır.

Cambra ve diğerleri (2013) İspanya'da, Verfaillie ve d’Ydewalle (1987) Belçika'da, Jelinek Lewis ve Jackson (2001) ABD'de, Jensema (2000; 2003) de yine ABD’de çocuklar için ayrıntılı altyazının önemi, standartları ve özellikleri hakkında önemli araştırmalar yaparak alana farklı ülkelerden katkılarda bulunmuşlardır.

Zárate (2008; 2010) ve Zárate ve Eliahoo (2014) de sırasıyla Sağır ve işitme engelli çocuklar için ayrıntılı altyazı uygulamaları, Sağır çalışmaları ve görsel-işitsel çeviride önemi ve ayrıntılı altyazılarda Sağır ve işitme engelli çocukların sözcükleri tanıması ve içerik algıları konusunda çalışmalar tamamlamışlardır.

Görsel-işitsel çeviri odaklı bu çalışmaların yanı sıra uluslararası alan yazınında Sağır ve işitme engelli çocukların okuma hızları ve algılama düzeyleri konusunda yapılan çalışmalar da ayrıntılı altyazı çevirisi uygulamalarında yol gösterici niteliktedir. Örneğin, Powers ve diğerleri (1998), Sağır ve işitme engelli çocukların okuma alışkanlıkları ve okur profilleri, Marschark (1993) söz konusu çocukların diğer çocuklara kıyasla okuma güçlükleri, Allen (1986) aynı kitlenin okur-yazarlık gelişimi, Adams (1990) çocukların okumada bölümleme becerileri, Simpson ve diğerleri (1992) çocukların anlama algılama düzeyleri hakkında yaptıkları çalışmalarla çocuklar için ayrıntılı altyazı uygulaması yapacak profesyonellerin bilmesi gereken art alan bilgisini ortaya koymuşlardır.

Örneklenen çalışmalara bakıldığında birkaç önemli konu ön plana çıkmaktadır. Birincisi, Sağır ve işitme engelli çocuklar için ayrıntılı altyazı çevirisi yetişkinler için yapılandan farklılaşmalıdır. İkincisi, bu uygulamanın verimli olabilmesi için "ülke bazı" araştırma yapılması gerekmektedir. Hangi ülkede eğitim alırlarsa alsınlar Sağır ve işitme engelli toplulukların yazılı dile erişimi akranları ile aynı hızda olmamaktadır; ancak, gerek dil edinim düzeyi, hızı ve içeriği gerekse diğer sosyal gerçekler ülkeden ülkeye farklılık göstermektedir. Bunun nedenlerinden biri ülkenin söz konusu kitlenin eğitime erişimi için sağladığı olanaklardır. Diğer bir nedeni ise ailelerin sosyo-ekonomik durumlarıdır. Ayrıca, dillerin özellikleri, farklı ülkelerde benimsenen ayrıntılı altyazı gelenekleri ve daha birçok etmen de bu uygulamanın etkinliğini etkilemektedir.

Dolayısıyla, giriş bölümünde de söz edildiği üzere Türkiye'de son zamanlarda Sağır ve işitme engelli çocuklar için ayrıntılı altyazı seçeneğinin sunulmasının düşünülmesi, bu konuda çok dar kapsamda da olsa bir ilk araştırma yapılmış olması, çok önemli bir gelişmedir. Ancak bu gibi çalışmalar arttıkça alan gelişebilecektir. 


\section{Türkiye'de Sağır ve İşitme Engelli Çocuklar için Ayrıntılı Altyazı Çevirisi Hakkında bir Araştırma ve Uygulama Projesi}

Sağır, İşitme Engelli ve Görme Engelli Çocukların Televizyon Programlarına Engelsiz Erişimi Projesi, başlığından da anlaşılacağı üzere, sesli betimleme, ayrıntılı altyazı çevirisi ve işaret dili çevirisi proje bileşenlerinden oluşmuştur. Söz konusu bu çalışmada ise sadece ayrıntılı altyazı konusundaki proje döngüsüne ve çalışmalara değinilmektedir.

SEBEDER (Sesli Betimleme Derneği) tarafından yürütülen projenin (dernek hakkında ayrıntılı bilgi için bkz. SEBEDER, 2020) ayrıntılı altyazı bileşenine, görsel-işitsel çeviri konusunda deneyimi olan iki ayrıntılı altyazı çevirmeni, iki Sağır editör ve çevirmen, bir Türkçe dil editörü, beş Türk işaret dili çevirmeni ve İstanbul Üniversitesi Çeviribilim Bölümü, Hacettepe Üniversitesi ve Bilkent Üniversitesi MütercimTercümanlık Bölümleri ve Sinop Üniversitesi-Okul Öncesi Eğitim Bölümünden akademisyenler katkı sağlamıştır. Proje Ağustos 2020'de başlatılmış yoğun bir çalışmayla Ekim 2020'de tamamlanarak SEBEDER'e teslim edilmiştir. Projenin ayrıntılı altyazı bileşeninin ana amaçları, Sağır kültürde büyüyen ve Türk İşaret Dilini (TiD) ana dili olarak kullanan çocukların ve işitme engelli olup ayrıntılı altyazı ile programlara erişimi olan çocukların çocuk programlarına duydukları ilgiyi arttırmak; söz konusu alıcıların programları izleme zevkini perçinlemek; yayınlara erişimle gelişen "yaşam ve toplumlaşma" becerilerini geliştirmek ve diğer çocuklar ile aynı haklara sahip olarak, yaşıtlarıyla eşit edinimlerini ve erişimlerini sağlamak olarak belirlenmiştir.

\subsection{Ayrıntılı Altyazı Çevirisi Proje Bileşeni Hakkında Genel Bilgi}

Proje bileşeninin ayrıntılı hedefleri, ana dilleri işaret dili olan Sağır ve/ya işitme engelli çocuk alıcılar için ayrıntılı altyazıyla erişilebilir çeviri kaynaklar oluşturmak; çalışmadan elde edilecek veriler ve dönütlerle benzer kaynakların oluşturulması için akademik açıdan onanmış bir proje döngüsü ve bir çeviri kılavuzu oluşturmak; oluşturulan proje döngüsünden elde edilen deneyimle, söz konusu alıcıların, sözü edilen programlara erişimlerini destekleyecek çalışmalara katkı sağlamak ve bu çalışmaları yaygınlaştırmak; akademik araştırmalardan ve SEBEDER'in uygulamalarından elde edilen, erişimde çevirinin niteliğini geliştirmek için kullanılabilecek bilgileri ve birikimi uygulamaya yansıtmak olarak belirlenmiştir.

Proje kapsamında çeviribilimciler, işaret dili çevirmenleri, ayrıntılı altyazı çevirmenleri ve editörleri bir araya getirilmiş ve bir iletişim ve mesleki paylaşım köprüsü kurulmuştur. Bileşende on beş çocuk programı (çizgi film, eğitici içerikli programlar, vb.) ayrıntılı altyazı çevirisi ile çevrilmiştir. Edinilen deneyim ve yapılan araştırmalardan yola çıkarak bir proje kılavuzu, dil editörü ve Sağır editör için de iki kılavuz derlenmiştir. SEBEDER'in, projenin üçüncü döngüsünde Sağır raportörler, anketçiler ve ebeveynlerle birlikte Sağır ve işitme engelli çocuklarla yürüttüğü odak grubu çalışmasından elde edilen sonuçlar da projenin kalitesini onaylar nitelikte olmuştur. 
Türkiye'de Sağır ve İşitme Engelli Çocuklar için Ayrıntılı Altyazı Çevirisi Hakkında Bir Araştırma:

Uygulamada Sadeleştirme

Proje, a) Planlama (süreçlerin, paydaşların, amaç ve hedeflerin, zaman çizelgelerinin ve çalışma şekillerinin vb. belirlenmesi), b) Uygulama (çevrilecek ürünlerin incelenmesi, çeviri yaklaşımlarının belirlenmesi, pilot çeviriler üzerinden çeviri stratejilerinin belirlenmesi ve çeviri kılavuzunun ilk taslağının oluşturulması, çevirilerin yapılması, editörlük süreci vb.) ve c) Kontrol (odak grubu çalışmaları, verilerin gözden geçirilmesi, kılavuzların nihai hâle getirilmesi vb.) evrelerini içermiştir.

Proje ayrıntılı altyazı bileşeninde ana kısıt şu şekilde özetlenmiştir: Görsel-işitsel ürünlerin işitsel kanalına "sesle" değil de "yazıyla" (altyazı ile) erişildiğinde, bir işitsel düzgü (üründeki sesler), özünde görsel olan bir düzgüyle (yazı - altyazı) ikame edilir. Söz ve yazı arasındaki algı ve edinim hızı farkı göz önüne alınarak çeviri yapılmalıdır. Örneğin, her bireyin duyduğunu algılama hızı ile okuduğunu hem okuma hem de algılama hızı farklıdır.

Ana sorunsal ise şu şekilde ifade edilmiştir: Uygulamada, çoğu ürünün "işiten dünyaya erişimi olan" çocuğa yönelik olarak tasarlandığının bilinciyle hareket etmek önemlidir. Dünyada herkes için tasarım (design for all) uygulamasına geçilememiştir. Dolayısıyla, ayrıntılı altyazı eklemesiyle ortaya konan ürün her anlamda bir 'çeviri üründür'. Ürünün alıcısının kültürü ve üreticisinin kültürü arasında örtüşüm olabileceği gibi, farlılıklar da olacaktır. İki alıcı kitlenin (Sağır ve işitme engelli çocuk ve diğer çocuklar) "işiten kültürdeki kültür birikimine, dünya bilgisine erişimi" arasında da farklılıklar olacaktır. Sağır çocuğun kendi kültüründe ve dilinde olmayan kavramların ve hatta düşüncelerin kaynak metinde olabileceği unutulmamalıdır.

Projede sunulan kılavuzun amacı şu şekilde açıklanmıştır: Söz konusu olan kısıtlar (yapılamayacaklar) ve parametreler (olasılık, değişken ya da etkenler) bağlamında oluşturulacak her kılavuz çevirmene çeviri felsefesi ve sıkça karşılaşılan sorunlar hakkında yol gösterici olabilir. Ancak, ürünlerin çeşitliliği, çeviri sürecinde çıkabilecek sorunların çeşitliliği ve bunların değişik parametreler içinde değerlendirilmesinde çıkabilecek farklılıkları göz önüne aldığımızda, bir kılavuzda, çevirmenlerin soracağı tüm sorulara, karşılaşacakları tüm çeviri sorunlarına cevaplar veya çözümler olamaz. Aynı mantıktan hareketle, önerilen yöntemlerin ve yaklaşımların her bağlamda uygulanabilir olması beklenemez.

Yukarıda sözü edilen konulardan dolayı sözü edilen tarzda bir projede çalışabilecek ayrıntılı altyazı çevirmeni, dil editörü ve Sağır editör profilleri, yetkinlikleri önem taşıdığı için ayrıntıları ile açıklanmıştır. Kılavuzun ilk bölümünde çeviri parametreleri ve altyazıların ekranda kalma süreleri konularına açıklık getirilmiştir. Yazım ile ilgili konular başlığı altında ise anlam birimlerine, öznenin kullanılmasının önemine ve ayrıntılı altyazı geleneklerine uygun noktalama işaretlerine dair bilgi verilerek belli standartlar önerilmiştir. Kılavuzun ana bölümü olan ve sorunsallar, standartlar/öneriler ve örneklerin anlatıldığı bölümde özellikle ayrıntılı altyazı bağlamında aşağıdaki konuların nasıl ele alınabileceğine öncelik verilmiştir:

- Karakter isimlerinin belirtilmesi

- Nidaların çevirisi 
- Şarkıların/müziklerin altyazıda verilmesi

- Söz/ses oyunlarının yansıtılması

• Bölüm başlıklarının/görseldeki yazıların çevirisi

- Yeni sözcükler aktarılması

- Sayıların yazımı

- Dış sesler ve ses efektlerinin verilmesi

Bu çalışmada ise, yukarıda belirtilen başlıklarda da kısaca değinilen, ancak Sağır ve işitme engelli çocuklar için ayrıntılı altyazı tasarımında merkezi önemde olan sadeleştirme yaklaşımına odaklanılan bölüm ele alınacaktır.

\subsection{Sağır ve İşitme Engelli Çocuklar için Ayrıntılı Altyazı Çevirisi Uygulamasında Sadeleştirme.}

Proje bileşeni içerisinde altyazıda sadeleştirme konusundaki çalışma ve uygulamaları tek bir başlık altında toplamak oldukça zordur. Bunun nedeni bir önceki bölümde sayılan başlıklar altında da (örneğin, nidalar, şarkılar vb.) sadeleştirme örneklerinin verilmiş olmasıdır. İkinci ve daha önemli nedeni ise sadeleştirmenin Sağır ve işitme engelli çocuğun ayrıntılı altyazı çevirisiyle ürüne erişmesi için bir yöntemden çok bir yaklaşım olmasından kaynaklanmaktadır. Dolayısıyla, somut örnekler verilebilse de verilen örnekler sadece yaklaşımın kabaca sınırlarını çizebilir ve yaklaşımın çevirmenler tarafından uygulanmasını kolaylaştırabilir.

Ayrıntılı altyazı çevirisinde sadeleştirme kavramı çok genel hatlarıyla "konuşmada iletilen diyalogun aynıyla altyazıya aktarılmaması ve engelsiz erişime uygun öz ve etkin bir metnin sunulması" olarak tanımlanabilir. Söz konusu projede benimsenen sadeleştirme yaklaşımının iki temel amacı vardır. Bunlar sırasıyla, çocuk alıının okuma hızını dikkate alarak "okuyabileceği" bir metin yaratmak ve çocuk alıcıya görsel olarak (altyazı olarak) sunulan işitsel düzgünün (diyalogların) "algılanabilir" olmasını sağlamaktır.

Sadeleştirme yaklaşımı (providing plain subtitles), bir metni basite indirgeme (simplifying subtitles) ile karıştııımamalıdır. Sadeleştirme sorasında Sağır ve işitme engelli çocuk alıııya iletilen bilgide bir azalma söz konusu değildir. Çocuk alıcının izleme zevkini olumsuz olarak etkileyecek yaklaşımlardan kaçınılır.

Bir ayrıntılı altyazı metninde sadeleştirme yaklaşımı benimsenirken düşünülmesi gereken bazı temel konular vardır. Çevirmenin altyazıyı sunacağı programın hitap ettiği yaş grubu hakkında (genel kültür ve akademik birikim, dünya bilgisi vb. açılardan) genel bir fikri olması gerekir. Ayrıca, programın hitap ettiği yaş grubunun ortalama okuma hızı hakkında da bilgisi olması önemlidir. Programın hitap ettiği yaş grubunun sözcük ve kavram dağarcığını geliştirme becerisi ve hızı konusunda bir fikir sahibi olmak da yararlıdır. 
Türkiye'de Sağır ve İşitme Engelli Çocuklar için Ayrıntılı Altyazı Çevirisi Hakkında Bir Araştırma: Uygulamada Sadeleştirme

\subsubsection{Sadeleştirme İçin Çeviri Stratejileri}

Ayrıntılı altyazıda sadeleştirme bir yaklaşım olduğundan, bu yaklaşımın altında birçok farklı çeviri stratejisi kullanılabilir. Bu çeviri stratejilerine örnek vermek konuya açıklık getirecektir.

Birinci strateji kaynak metindeki sözcük, kavram vb. sayısında azaltmaya gitmek olarak açıklanabilir. Örneğin, görselde bir grup çocuk görünür. Bir yere gidilmesi düşünülmektedir. Kaynak işitselde replik "Sen, ben, Ayşe, Can, Hasan, hep birlikte gidelim" şeklinde dillendirilir. Alıcı altyazıyı okurken ve anlamlandırırken görselden de destek alınacağı için (repliği söyleyen çocuk ve diğer çocuklar sahnede göründüğü için) bu replik "Hep birlikte gidelim" olarak yansıtılabilir.

İkinci strateji kaynak metindeki cümle yapısını değiştirmeyi içerir. Altyazıda devrik cümlelerin kullanımı okumayı ve anlamayı olumsuz etkiler. Dolayısıyla, bu cümlelerin kurallı cümlelere çevrilmesi uygun olabilir. Örneğin "Ne diyeceksin bu konuyla ilgili?" cümlesi yerine "Bu konuda ne diyeceksin?" cümlesi daha kolay anlaşılacaktır.

Üçüncü strateji kaynak metindeki diyaloğu aynıyla aktarmak yerine amaçlanan anlamı veya etkiyi yaratacak eşdeğeri ile karşılamaktır. Örneğin, sözlü dilde vurgu, sesletim ve benzeri ile anlamlanan nidaların altyazıda yansıtılması sorun olabilir. Bu tür nidalara aşina olmayan çocuk alıcılar için nidaların altyazıda yansıtılması kimi zaman kafa karışıklığına neden olmakta, kimi zaman da altyazı metnini anlaşılmaz kılmaktadır. Mesela, aşağıda "Aa" nidası ile ilgili olarak parantez içinde verilen açıklamalara bakıldığında bu nidanın anlamının bağlama göre farklılaşabileceği gözlemlenebilir:

\begin{tabular}{|l|}
\hline A: Ayşe okula gitmedi. \\
B: Aa..(şaşırma ifadesi) \\
\hline A: Ayşe okula gitmedi. \\
B: Aa.. (sinirlenme ifadesi) \\
\hline A: Ayşe okula gitmedi. \\
B: Aa.. (kötü olmuş, ne kadar yazık olmuş anlamında kullanılan ifade) \\
\hline
\end{tabular}

Bir başka örnek ise "Ah" nidasıdır.

Örneğin, bir çocuk düşüp canı acıdığında "ah" nidası çocuğun canının yandığına işaret ederken, bir başka örnekte aynı nida tamamen başka bir anlama gelebilir:

A: Peynir aldın mı?

B: Ah, unuttum (tüh, ne yazık ki, üzgünüm anlamında kullanılan ifade)

Bu gibi bağlamlarda, çevirmenin, yukarıda verilen örnekteki nidadan da anlaşılacağı üzere, üç seçeneği vardır. Birincisi, nidayı aktarmaktır. Bu bağlamda, görselden destek aldığına (örneğin, kurguda ve görselde karakterin canı acıdığı için "ah" dediğinin belli olduğuna) emin olduğu durumlarda, nidayı aynıyla altyazıya yansıtabilir. İkincisi ise nidanın kullanımı ile amaçlanan anlamı yansıtarak açımlama tekniğini kullanmaktır. Örneğin, “Ah, unuttum” yerine "Unuttum. Özür 
dilerim/üzgünüm" şeklinde çevirmesidir. Üçüncüsü ise nidayı tamamen çıkartmaktır. Örneğin,
A: Ayşe 10 yaşına bastı
B: Ya. Öyle mi. Çok büyümüş.

yerine
A: Ayşe 10 yaşına bastı
B: Öyle mi? Çok büyümüş.

Nidalar söz konusu olduğunda, çevirmenin aşağıdaki parametreleri düşünerek bir çeviri seçimi yapması gerekir:

- Nida altyazıda yansıtıldığında kafa karıştırıyor mu?/Anlamayı zorlaştırıyor mu?/Metni anlamsızlaştırıyor mu?

- Nida altyazıda yansıtılmazsa (çıkarılsa), metinde (üründe) bir anlam kaybı veya ifadedeki duygu yükünde (üzüntü, sevinç vb.) bir farklılık oluyor mu?

- Nida olduğu gibi yansıtılamıyor veya çıkarılamıyorsa, bu nida metinde hangi duyguyu, düşünceyi vb'ini ifade ediyor ve bu yazı dilinde nasıl yansıtılabilir?

Nidaların çevirisi kaynaktaki diyaloğu aynıyla aktarmak yerine amaçlanan anlamı veya etkiyi yaratacak eşdeğeri ile karşılama stratejisine güzel birer örnektir.

Dördüncü strateji kaynaktaki iletiyi daha anlaşılır kılmak için yeniden dillendirerek/düzenleyerek yazmayı içerir. Bu bağlam için de dış seslerden ve ses efektlerinden örnek verilebilir. İşitsel kanaldan aktarılan dış sesler ve ses efektlerinin altyazı metninde yer alması kimi zaman metnin anlaşılması için önemlidir. Kimi zaman da çocuk alıcı için başa çıkılamayacak bir okuma yükü getirir. Dolayısıyla, dış ses ve efektlerin bazı kısıtlar ve parametreler düşünülerek altyazı metnine yansıtılması önemlidir.

Çevirmen "Dış ses ve/ya efekt hikâyenin bütünlüğü içinde merkezi bir anlam ifade ediyor mu?" sorusuna vereceği cevaba göre dış ses veya efekti altyazıya dahil etmemeye; dış ses veya efekti altyazıda kısaca aktarmaya veya dış sesi yansıtmaya karar verebilir. Örneğin, bir sahnede çocuklar bir parktan geçerlerken çevrelerinde kuş cıvıltıları duyulmaktadır. Çevirmen bu sesi aktarmak için (zaman ve uzam kısıtı yüzünden) diyalogları kısaltmak zorunda kalacaksa bu gereksiz olabilir. Ortamın park olduğu görselden anlaşılmakta, kuş cıvıltısı sesi ise verilen örnekteki hikâyede merkezi bir önem taşımamaktadır. Ancak, başka bir örnekte dış ses merkezi önemde olabilir. Örneğin, bir çocuğun düştüğü ve acıyla bağırdığı duyuluyor. Çocuk karakterler de düşme sesini duyunca arkadaşlarına yardıma koşuyorlar. Bu örnekteki dış ses önemlidir ve altyazıda yansıtılması düşünülmelidir.

Bir diğer deyişle, dış sesin ve/ya efektin hikâyede ne kadar etkin bir öge olduğu önemlidir. Çevirmen görseli ve hikâye akışını dikkate alarak dış ses veya efekti yansıtıp yansıtmamayı seçebilir. Örneğin, çocuk karakterler komiklik olsun diye telsizle konuşuyormuş gibi yaparak telsiz sesi çıkarırlar. Karşı karşıya durmalarına rağmen 
Türkiye'de Sağır ve Iş̧itme Engelli Çocuklar için Ayrıntılı Altyazı Çevirisi Hakkında Bir Araştırma: Uygulamada Sadeleştirme

ellerinde telsiz tutuyormuş gibi ellerini ağızlarına yakınlaştırıp birbirleriyle telsizle konuşuyorlarmış gibi yaparak oyun oynarlar. Bu örnekte görselle de desteklenen bir dış ses (telsiz cızırtısı) vardır. Bu ögenin altyazıda yansıtılmaması görselin anlamsızlaşmasına neden olacaktır. Başka bir örnekte, çocuk karakterler bahçede bir deney yapmaktadırlar. Deneyde bir tartıyı dengede tutmaya çalışırlar. Tartı dengede durmayınca tartının üstünde duran bir kova su tartının önünde duran çocuğun üstüne dökülür ve çocuk ıslanır. Görselde kovanın devrildiği, suyun döküldüğü, çocuğun ıslandığı açıkça görülür. Bu gibi bir örnekte (su dökülme sesi) veya (su sesi) gibi bir açıklama eklenmesi gereksiz olabilir.

Dış sesin ve/ya efektin hikâyede hangi sıklıkla geçtiği de altyazıya yansıtılıp yansıtılmaması konusunda verilecek kararda önemli rol oynar. Bir dış ses veya efekt hikâyede atmosferi sağlamak için veya kurgunun merkezi bir parçası olarak kullanılabilir. Örneğin, bir robot ile bir sunucunun yer aldığı bir programda robot karakter (elektronik tuş sesleri çıkartarak) konuşur. Sunucunun etkileşim içinde olduğu bir "karakterdir". Robotu anlayan tek kişi sunucudur ve robota verdiği cevaplardan izleyenler robotun ne dediği konusunda çıkarımda bulunurlar. Bu tarz örneklerde bu anlaşılmayan sesin veya dış sesin altyazıda ("Robot konuşuyor" şeklinde) yansıtılması önemlidir. Aksi takdirde karakterlerin etkileşimi anlaşılmayacaktır. Dış ses ve efektlerin ayrıntılı altyazıda yansıtılması dördüncü sadeleştirme stratejisi olan kaynaktaki iletiyi daha anlaşılır kılmak için "yeniden dillendirerek/düzenleyerek yazmaya" güzel birer örnektir.

Beşinci çeviri stratejisi ise kaynak sözlü iletiyi yazı dilinde ölçünlü bir dille ifade etmek, yani ölçünlü yazı dilini kullanmaktır.

\subsubsection{Sadeleştirmede Temel ilkeler}

Yukarıda örneklendirilen çeviri stratejileri çocuk alıcıya yönelik ayrıntılı altyazı çevirisi yapılırken başvurulacak temel stratejiler olarak kabul edilebilir. Söz konusu çeviri stratejilerini kullanırken sadeleştirmede benimsenecek temel ilkeleri de kısaca anlatmak hem uygulayıcı hem de araştırmacılar açısından konuyu daha iyi anlamak için önemlidir.

Sadeleştirmede göz ününde tutulması gereken temel ilkelerden birincisi görsel destek konusudur. Görselde var olan bir öge ancak altyazıda uzam ve zaman kısıtı olmadığı durumlarda yansıtılmalıdır. Örneğin, "Şimdi de sağdaki mavi küçük çekmecemizi açıyoruz" repliği iletildiği sırada belirtilen çekmece yakın çekimdeyse, mavi olduğu, küçük olduğu ve sağda olduğu belli ise, başka bir çekmece ile karıştırılması olası değilse ve bu repliğin geçtiği bağlamda uzam ve zaman kısıtı varsa, söz konusu betimlemeler çıkartılabilir ve konuşma altyazıda "Şimdi öteki çekmeceyi açtım" şeklinde ifade edilebilir. Yani, görselden destek bilgi ediniliyorsa, bilgi eksiltilmiyorsa, sözcük sayısındaki eksiltme kafa karışıklığına neden olmuyorsa, zaman ve uzam kısıtı varsa (karakter sayısı aşılıyorsa ve çok hızlı konuşulduğu için altyazı çok kısa süre ekranda kalacaksa) sadeleştirme yapılabilir. 
İkinci olarak sadeleştirme yaklaşımında kaynak metinde kullanılan zamanlar altyazıda aynıyla yansıtılmayabilir. Çocuklara yönelik yazılı anlatılarda bazı zamanlarda değişikliğe gidilebilir. Zaman kullanımlarında değişiklik yapılacağı durumlarda dikkat edilmesi gereken bazı konular vardır. Birincisi, anlam kayması olmamalıdır (örneğin, ekranda yapıldığı görülen bir şeyin gelecek zamanda verilmemesi). Yazılanın ekrandaki görüntüyle eş süremli bir şekilde verilmesi gerekir. Örneğin, altyazıda (sunucu kırmızı bir kurdeleyi keserken) "Evet çocuklar. Şimdi de kırmızı kurdelemizi keselim bakalım... kestik" yazmak yerine "Çocuklar şimdi kırmızı kurdeleyi kestik" yazılabilir.

Üçüncü olarak sadeleştirmede anlamaya katkıda bulunmayan sözcükler ve ifadelerin çıkarılması da söz konusudur. Anlamaya katkıda bulunmayan sözcüklere kimi nidalar, tekrarlar veya görselde de açıkça seçilebilen betimlemeler örnek olabilir. Örneğin, çocuk programlarında sıkça tekrar yapılmakta, bu uygulama sözlü anlatıda anlamayı pekiştirmektedir. Ancak, bu tekrarlar yazılı olarak iletildiğinde (çocuk alıcının okuma hızı nedeniyle) metnin okunmasını engellemekte ve çocuğun metni takip etmesini ve anlamasını olumsuz etkilemektedir. Dolayısıyla, çevirmenin tekrarlarda okuma hızını düşünerek aktarımda sadeleştirme yapması gerekebilir. Bu konuda karar verirken, çevirmenin zaman ve uzam kısıtını, söz konusu tekrarın metnin anlaşılması için merkezi önemde olup olmadığını, söz konusu tekrarın çocuğun okuduğunu anlamlandırmasını olumsuz etkileyip etkilemeyeceğini tartması ve ona göre karar vermesi gerekir.

Sunucusu olan çocuk programlarında, program sunucuları, çocukların ilgisini programda tutmak ve her yapılanı açıklamak için genelde fazla sessiz ara bırakmadan, sözlü dilde kolay algılanabilen bir hızda (oldukça hızlı) konuşur. Ancak, bu durmayan dil akışı ve anlatı aynıyla altyazıya aktarılırsa o zaman çocuk alıcının bunu okuyup anlaması zor olabilir. Dolayısıyla, sözü uzatmak, açıklamak, tekrarlamak veya izleyicinin ilgisini programda tutmak için iletilenlerin çevirmen tarafından değerlendirilmesi ve çocuk alıcının okuma hızı göz önüne alınarak kimi yerde kısaltmaya gidilmesi gerekebilecektir.

Bir başka sadeleştirme ilkesi ise sesletimle anlamlanan diyalogların açımlanmasıdır. Sözlü dille iletişime özgü bazı kalıplar ve/ya yapılar vardır. Bunlar yazı diline aktarıldığında çocuk alıcılar için anlamlı olmayacaktır:

Cafer: Ben de on dondurma yerim o zaman! (Cafer ciddi bir ifadeyle söyler.)

A: Ay sen de Cafer...

Yukarıdaki örnekte, repliğin sesletilişine göre "Ay sen de Cafer..." repliğinin farklı olası anlamları vardır: "Cafer, saçmalama on dondurma yenilmez", "Cafer çok komiksin, hiç on dondurma yenilir mi", "Cafer, on dondurma yemek doğru değil (hastalanırsın)". $\mathrm{Bu}$ replik, işitsel düzgüdeki sese ve vurguya erişimi olan biri için verilen anlamlara gelebilir. Ancak, işitsel düzgüye erişemeyen biri için "Sen Cafersin", "Her ne yapılıyorsa/oluyorsa Cafer de bu gruba dâhil/yapsın", "Cafer'e bir şey söylenecekti ve cümle yarıda kaldı" gibi anlamlara gelebilmektedir.

Çevirmenin bu gibi durumlarda, yazılı dil ve sözlü dil arasındaki farkı düşünerek; kaynak metinde amaçlanan anlama sadık kalarak; kaynak metindeki duyguyu yansıtarak; çeviri kısıtlarını dikkate alarak çevirisinde "anlam odaklı" bir yaklaşım 
Türkiye'de Sağır ve İşitme Engelli Çocuklar için Ayrıntılı Altyazı Çevirisi Hakkında Bir Araştırma: Uygulamada Sadeleştirme

benimsemesi gerekir. Yukarıda verilen örnekten hareketle, bu replik (amaçlanan anlam Cafer'in komik olduğunu belirtmekse), "Komiksin Cafer" veya (amaçlanan anlam Cafer'in önerisinin kabul edilemeyeceğini belirtmekse) "Yapma Cafer" veya (amaçlanan anlam Cafer'in söylediğine kızmaksa) "Olmaz Cafer” gibi çevrilebilir.

Beşinci olarak sadeleştirme yapılırken hece sayısına dikkat etmek önemlidir. Özellikle okumayı yeni öğrenen çocuk alıcıları göz önünde bulundurarak altyazıda kullanılacak sözcüklerdeki hece sayısına dikkat ederek çeviri yapmak gerekecektir. Örneğin, "illk başta arkadaşlarımızı tanımadığımız için ayrıştıramayabiliriz; isimleriyle hitap edemeyebiliriz" cümlesi okuma hızı gelişmemiş bir çocuk için oldukça zordur. Dolayısıyla, bu gibi cümlelerle karşılaşıldığında "Okul başlarken herkesi tanımayız. İsimlerini bilmeyiz" olarak sadeleştirilebilir. Önemli olan, cümlenin anlamında bir kayma veya kayıp olmadan, hikâyede kopukluk olmadığına emin olarak anlamı aktarırken okuma hızını da dikkate almaktır.

Bir sonraki ilke eksiltili cümleleri kapsamaktadır. Sadeleştirme yaklaşımında metnin anlamlanmasını kolaylaştırmak hedeflendiğinden yarım kalan cümlelerin geçtiği durumlarda çevirmen tamamlanmayan cümlenin sonuna üç nokta (...) veya tire (-) ekleyebileceği gibi, eğer bunun kafa karıştıracağını düşünüyorsa cümleyi tamamlamayı da düşünebilir:

A: Bence sen yanlış yapıyorsun!
B: Ama- (Ĕger B karakteri neden yaptı̆̆ına itiraz edildiğini anlamadıysa ve
açıklanmasını istiyorsa)

ya da

A: Bence sen yanlış yapıyorsun!

B: Ama neden? (Eğer B karakteri kendini savunmaya çalışıp arkadaşının yargısına karşı çıkıyorsa)

ya da
A: Bence sen yanlış yapıyorsun!
B: Hayır!

Konuşma sırasında belli nedenlerden dolayı (örneğin, başka birinin araya girmesi ve sözünü kesmesi, konuşurken kendini ifade edeceği sözcükleri bulamaması, dikkatinin dağılması, vb.) karakterlerin cümleleri yarım kalabilir, ancak çevirmen altyazıda cümleyi tamamlamadan bırakıp bırakmayacağına karar verecektir.

Yukarıda sayılan genel ilkelere ek olarak değinilmesi gereken diğer önemli konular karakter isimlerinin, çocuk programlarında çoğunlukla yer alan şarkıların, söz oyunlarının ve kafiyelerin nasıl aktarılacağıdır. Illk olarak sadeleştirme yaklaşımında karakter isimlerinin yansıtılıp yansıtılmayacağına bakacak olursak, yazı dilinde (altyazıda) karakter isimlerinin belirtilmesinin çocuk alıcı açısından bir okuma yükü getirebileceğini düşünebiliriz. Görselde kimin konuştuğunun açıkça belli edilmediği durumlarda, altyazının uzun olması durumunda, çocuk alıcının görsele yeterince dikkat edememesi durumunda, dış seslerin olduğu kurgularda ve benzeri durumlarda alıcı 
açısından "kimin konuştuğunun" ayrıştııılması da önemlidir. Dolayısıyla, karakter isimlerinin yazılacağı durumlar olacaktır. Çevirmenin görselden edinilen bilgiyi, yani karakterin ekranda görünüp görünmediğini, kimin konuştuğunun belli olup olmadığını ve benzeri unsurları tartarak, bir seçim yapması gerekir. Karakter isimlerinin tümünün BÜYÜK HARF olacak şekilde ve diyaloglardan ayrıştırılacak şekilde, örneğin ismin ardından iki nokta üst üstte konularak (:) yazılması öngörülebilir.

Karakter isimleri Türkçede kullanılan ölçünlü isimler olduğunda çevirmen bu isimleri aynıyla yazı diline yansıtır. Ancak, bazı karakter isimleri lakap olabilir (burnu akan bir çocuğa arkadaşlarının "AKIŞKAN" adını takması gibi) veya örneğin, o karakteri betimlemeye yönelik olarak türetilmiş "uydurulmuş isim" olabilir (örneğin, Sürpriz Kutusu ${ }^{2}$ isimli çocuk programında sunucuya eşlik eden "bilgisayar/robot" benzeri bir karaktere "DÖNÜŞTÜRATÖR" isminin verilmesi gibi). Bu gibi durumlarda çevirmenin seçim yapması gerekir. Seçimlerini aşağıda belirtilen belli parametreleri kullanarak yapabilir.

Örneğin, sözü edilen karakter için kullanılan "isim” alıcı kitle için anlamlıysa aynıyla yazılır. Mesela, çok hızlı koşan veya tepki veren bir robotun adı IŞIK HIZI ise bu isim aynıyla kullanılabilir. Söz konusu yaş grubunun "ışık hızını" bildiği varsayılıyorsa ve ismin yazılması altyazı uzam kısıtlarına (karakter ve satır sayısı) uyuyorsa, o zaman bu ismin aynıyla yazılması bir sorun yaratmayacaktır. Ancak, sözü edilen karakter için kullanılan isim alıcı kitlenin okumasını zorlaştıracaksa farklı bir şekilde ifade edilmesi gerekebilir. Örneğin, yukarıda verilen örnekte, "DÖNÜŞTÜRATÖR" adı verilmiş karakter, sunucuya el işi projeler yapması için belli şekillerde dönüştürebileceği malzemelere ve bu malzemeleri nasıl kullanabileceğine dair bilgi vermektedir. Karakter ismi altyazıdaki uzamsal kısıtları zorlayacak oranda uzunsa ve isimle gönderme yapılan söz oyununun (malzemelerin el işi projelere dönüştürülmesi vb.) alıcı kitle tarafından anlaşılmayacağı düşünülüyorsa, kapsayıcı bir tabir kullanılması düşünülebilir (örneğin, ROBOT).

Sadeleştirme yaklaşımı içinde şarkıların ve müziklerin çevirisini de ele almak gerekir. Şarkı ve müzik kavramı Sağır kültürde de vardır. Ancak, işiten dünyaya özgü şarkı ve müzik geleneği ile birebir örtüşmez. Dolayısıyla, gerek şarkı sözlerinin yansıtılmasında gerekse jenerik veya geçiş müziği olarak kullanılan sessel ögelerin yansıtımında çevirmenin bazı seçimler yapması gerekir. Çevirmen bu seçimleri yaparken yine bazı kısıtları ve parametreleri düşünerek hareket etmelidir. Müziğin ürünün anlaşılması için merkezi önemde olup olmadığı yine alınacak kararlarda belirleyici olacaktır. Sahne geçişleri genelde merkezi önemi olmayan müziğe örnektir. Mesela, bir sahneden diğerine geçerken ürünün jenerik müziği çalıyorsa ve aynı zamanda görselde de bir sahne geçişi görünüyorsa, çevirmen bunu altyazıya yansıtmamayı seçebilir. Çocuk alıcı sahnenin değiştiğini görselden anlayacaktır. Ayrıca, alıcı için "jenerik müziği" ifadesi bir anlam ifade etmeyebilir ve gereksiz okuma yükü getirebilir. Ancak, sahne atmosferi yaratmak için kullanılan müzikler ve şarkılar söz konusu olduğunda çevirmenin daha dikkatli olması gerekebilir. Örneğin, bir sahnede

\footnotetext{
${ }^{2}$ Programa ilişkin bilgiye https://www.trtcocuk.net.tr/oyunlar/surpriz-kutusu adresinden ulaşllabilir.
} 
Türkiye'de Sağır ve İşitme Engelli Çocuklar için Ayrıntılı Altyazı Çevirisi Hakkında Bir Araştırma: Uygulamada Sadeleştirme

çocuklar oyun parkında çok eğleniyorlar ve fonda sözleri olmayan neşeyi, eğlenceyi çağrıştıran bir müzik çalıyorsa bu sessel öge atmosferi yarattığı için önemli görülebilir. Bu durumda, çevirmenin bu şarkının yarattığı atmosferi yazılı dilde nasıl ifade edeceğini belirlemesi ve örneğin "neşeli müzik" türünde bir betimleme yapması gerekebilir.

Aynı şekilde bir şarkının, hikâye örgüsüne bir art alan bilgisi ekleyip eklemediği veya hikâyedeki bir konuya vurgu yapıp yapmadığı karar verirken önem taşır. Jenerik şarkıları buna çok güzel örnektir. Bazı jenerik şarkılarında, üründe anlatılacak karakterler veya olaylarla ilgili bilgi verilebilir. Örneğin, Rafadan Tayfa ${ }^{3}$ çizgi filminde jenerik şarkısında Rafadan Tayfa'nın nasıl bir grup olduğu ve ne yaptıkları anlatılmakta ayrıca hikâyelere bir giriş sunulmaktadır. Bu gibi bağlamlarda sadeleştirme yaklaşımı kullanılarak, her satır başına nota işareti $(\delta)$ konulup şarkının aktarıldığı belirtilerek, şarkıdaki tekrarlar (nakaratlar) en aza indirgenerek, anlam bozulmadan ve Türkçe ölçünlü yazı dilinde aktarılarak, uyakları da aktarmaya özen göstererek çeviri yapılabilir.

Hikâye kurgusu içinde yer alan şarkıların altyazıda yansıtılıp yansıtılmayacağının da iyi düşünülmesi gerekir. Bazı ürünlerde, karakterler bir şarkı söyleyebilirler ya da fonda bir şarkı çalar ve bu şarkı hikâyedeki bir unsuru vurgulamak için kullanılır. Örneğin, yalancı bir karakterin anlatıldığı bir bölümde karakterin arkadaşları "Yalancı Çoban" şarkısını söyleyebilirler veya şarkı (sözleriyle birlikte fonda çalabilir). Bu gibi durumlarda çevirmenin belli seçimler yapması gerekir. Çevirmen, ilk önce şarkıyı yansıtabilecek uzama ve zamana sahip olup olmadığına bakmalıdır. Şarkının geçtiği saniyeler içinde (alıcının okuma hızını da düşünerek) şarkıyı yansıtabilme olasılığı yoksa, yalnızca şarkının ana içeriğini yansıtmayı uygun görebilir (Örneğin: SYALANCI, SANA KIMSE INANMAZS) veya şarkı alıcılar tarafından biliniyorsa ya da başlık yeterince açıklayıcı ise şarkının adını yazabilir (Örneğin: SYALANCI ÇOBANઈ). Şarkının sözlerini yansıtabilecek uzama ve zamana sahipse, sadeleştirerek şarkı sözlerini yazabilir.

Çevirmen sadeleştirme yaparken şarkı veya müzik ögesinin tamamen çıkarılmasının metnin anlaşılmasını zorlaştırıp zorlaştırmadığını veya izleme zevkinden eksiltip eksiltmediğini de düşünmelidir. Özetle, ilkesel olarak, hiçbir sessel ögenin metinde işlevsiz olduğu düşünülmemelidir. Asgari bir anlatıyla da olsa (örneğin, şarkı adı, şarkı ana fikri, şarkı olduğunun ifadesi vb.) aktarılması gerekir. Ayrıca, yine ilkesel olarak, söz konusu sessel öge ürünün anlaşılmasında merkezi öneme sahip değilse, çocuk alıcıyı gereksiz yere tekrarlarla okumadan soğutmamak gerekir. Örneğin, bir şarkıda aynı satırın 5 defa tekrarlanması gereksiz olabilir. Bunlara ek olarak, müzik ögesinin betimlemesi yapılırken (örneğin, "neşeli müzik") çocuk alıcının anlamayacağı türden betimlemeler veya uzun betimlemeler yapılmamalıdır (örneğin, "tehlikeyi çağrıştıran müzik".)

Söz/ses oyunlarının yansıtılmasında da sadeleştirme yaklaşımı benimsenebilecektir. Ürünlerde geçen söz oyunlarının veya sesteş sözcüklerle yapılan oyunların altyazıya yansıtılması çevirmen için (kimi bağlamda) sorunlu olabilir. Şarkılarda ve benzer sessel ögelerde uyak gibi unsurların yansıtılması önemli olabilir;

\footnotetext{
${ }^{3}$ Programa ilişkin bilgiye https://www.trtcocuk.net.tr/rafadan-tayfa adresinden ulaşılabilir.
} 
ama anlam her zaman merkezi önemde olacaktır. Bu gibi durumlarda çevirmenin seçimler yapması gerekir. Çift anlamlı sözcükler/kullanımlar buna güzel bir örnektir. Bozuk para ile "yazı-tura" oynayan çocukların anlatıldığı bir sahnede, çocuklar bozuk parayı fırlatıp "yazı" veya "tura" derler. Para üç defa üst üstte yazı gelir. Bir çocuk da hep tura demiştir. Çocuk sinirlenir ve "Bu 'bozuk' para" veya "Bu para 'bozuk"' diyerek hem "bozuk paraya", hem de paranın hep yazı gelmesine göndermede bulunup espri yapar. Bu gibi durumlarda çevirmen söz konusu ögeyi vurgulamak için bir yol bulabilir. Örneğin, kullandığı programın kısıtlarına göre, eğik yazı ile yazabilir, tümünü büyük harfle yazabilir, farklı renkte yansıtabilir vb. Bu seçenekte sessel olarak algılanan "oyun" yazıda da algılanacaktır.

Aynı şekilde sadeleştirme bağlamında, uyaklı satırların yazı dilinde yansıtılması da bir başka önemli konudur. Eğer uyak, diyalog yazı diline yansıtıldığında aynı harflerle yansıtılıyorsa (örneğin, dana, ana, bana) çocuk alıcı bunu algılayacaktır. Ancak, uyak yapmak için cümle devrik yazılmışsa ve yazı dili geleneğine uygun değilse, çevirmenin uyağı yansıtmamayı düşünmesi gerekebilir. Uyak merkezi önemde değilse, uyağın değil, anlamın yansıtılması öncelik kazanacaktır.

\section{Sonuç}

Çalışma boyunca örneklerle anlatılan çeviri stratejileri ve sadeleştirmede temel ilkeler bağlamında düşünüldüğünde, Sağır ve işitme engelli çocuklar için ayrıntılı altyazı çevirisi uygulaması uzmanlık gerektiren, zorlu bir uğraştır. Her bir ögenin tartılması, ayrıntılı altyazının alıcılara uygun olarak tasarlanması konunun merkezinde yatan unsurlardır.

Dünyadaki gelişmelere koşut olarak Türkiye'de de uygulanması düşünülen Sağır ve işitme engelli çocuklar için ayrıntılı altyazı çevirisi konusunda daha çok çalışmaya ve araştırmaya gereksinim vardır. Sağır çalışmaları bağlamında Sağır çocukların dil edinimleri ve okuma becerileri gibi konularda; çeviribilimde ise ayrıntılı altyazı konusunda daha birçok çalışma yapılması gerekmektedir.

Çalışmada anlatılan proje bu anlamda önemli bir ilk adımdır. Ancak daha ilk adım olduğunu, eksikliklerinin zamanla giderileceğini unutmamak gerekir.

Doğal olarak uygulama (dünyanın her yerinde olduğu gibi) çalışmaların tamamlanmasını beklemeden başlayacaktır. Bu nedenle de Sağır ve işitme engelli çocukların dilsel gelişimi, sosyal etkileşimi ve genel kültürleri için çok önemli olan ayrıntılı altyazı ile erişim konusunda çalışmalar sürerken devam edecek uygulamada yetkin çevirmenlerin çalıştırılması, Sağır editörlerin denetimi altında çeviri yapılması, kılavuzların oluşturulması için akademisyenlerle iş birliğine gidilmesi ve Sağır ve işitme engelli çocuklarla odak grubu çalışmaları yapılması çok önemlidir.

\section{Kaynakça}

ABC. (2010). Industry guidelines on captioning television programs. https://www.abc.net.au/mediawatch/transcripts/1105_freetvguidelines.pdf 
Türkiye'de Sağır ve İşitme Engelli Çocuklar için Ayrıntılı Altyazı Çevirisi Hakkında Bir Araştırma: Uygulamada Sadeleştirme

Adams, M. J. (1990). Beginning to read: Thinking and learning about print. Cambridge, MA: Massachusetts Institute of Technology.

Allen, T. E. (1986). Patterns of academic achievement among hearing impaired students: 1974 and 1983. A. N. Schildroth \& M.A. Karchmer (Eds.), Deaf children in America (ss. 161206). San Diego, CA: College-Hill Press.

Baker, R. G., Lambourne, A. D. \& Rowston, G. (1984). Handbook for television subtitlers (revised edition). Winchester: IBA Engineering Division.

BBC. (2018). BBC subtitle guidelines. London: The British Broadcasting Corporation. http://bbc .github.io/ subtitleguidelines/.

Cambra i Verges, C., Leal Garcia, A. \& Silvestre, N. (2013). The Interpretation and visual attention of hearing impaired children when watching a subtitled cartoon. The Journal of Specialised Translation, 20, 134-146.

Chaume, V. F. (2012). Audiovisual translation: Dubbing. Londra \& New York: Routledge.

Chesterman, A. \& Wagner E. (2002). Can theory help translators? A dialogue between the ivory tower and the wordface. Manchester, UK, Northampton, MA: St. Jerome.

Chiaro, D. (2009). Issues in audiovisual translation. J. Munday (Ed.), The Routledge companion to translation studies (ss. 141-165). Londra \& New York: Routledge Taylor and Francis Group.

Çankaya, Ö. (1992). Türk televizyonunun program yapısı. İstanbul: Mozaik Basım ve Yayıncılık.

Danan, Martine. (2004). Captioning and subtitling: Undervalued language learning strategies. Meta, 49(1), 67-77.

De Higes Andino, I \& Cerezo Merchan, B. (2018). Using evaluation criteria and rubrics as learning tools in subtitling for the $\mathrm{D} /$ deaf and hard of hearing. The Interpreter and Translator Trainer, 12(1), 68-88.

De Linde, Z. \& Kay, N. (1999). The semiotics of subtitling. Manchester, UK: St. Jerome.

Delabastita, D. (1989). Translation and mass- communication: Film and tv translation as evidence of cultural dynamics. Babel, 35(4), 193-218.

Diaz-Cintas, J. \& Remael. A. (2007). Audiovisual translation: Subtitling. Manchester: St. Jerome.

Diaz-Cintas J., Matamala, A. \& Neves, J. (2010). Media for all: New Developments. J. Diaz-Cintas, A. Matamala \& J. Neves (Ed.), New insights into audiovisual translation and media accessibility (ss. 11-22). Amsterdam: Rodopi.

Doherty, S., ve Kruger, J. L. (2018). The development of eye tracking in empirical research on subtitling and captioning. J. Sita, T. Dwyer, S. Redmond, \& C. Perkins (Ed.), Seeing into screens. Londra: Bloomsbury.

EFHOH. (2011). State of Subtitling Access in EU. 2011 Report. Stockholm: EFHOH. http://ec.europa.eu/internal_market/consultations/2011/audiovisual/nonregistered organisations/european-federation-of-hard-of-hearing-peopleefhoh-_en.pdf

Gregory, S. ve Sancho-Aldridge, J. (1996). Dial 888: Subtitling for deaf children. Londra: Independent Television Commission. 
Jelinek Lewis, M. S. \& Jackson, D. W. (2001). Television literacy: Comprehension of programme content using closed captions for the deaf. Journal of Deaf Studies and Deaf Education, 6(1), 43-53.

Jensema, C. (2000). A study of the eye movement strategies used in viewing captioned television. Silver Spring, MD: Institute for Disability Research and Training. www.dcmp.org/caai/nadh130.pdf

Jensema, C. (2003). The relation between eye movement and reading captions and print by school-age deaf children. Wheaton, MD: Department of Education. www.dcmp.org/caai/nadh134.pdf

Marschark, M. (1993). Psychological development of deaf children. New York: Oxford University Press.

Media Access Australia. (2012). Captioning guidelines. https://mediaaccess.org.au/practicalwebaccessibility/media/caption-guidelines

Neves, J. (2008). Training in subtitling for the D/deaf and the hard-of-hearing. J. Diaz-Cintas (Ed.), The didactics of audiovisual translation (ss. 171-189). John Benjamins Publishing Company. 10.1075/btl.77.17nev.

Ofcom. (2013). Television access services: Report for the first six months of 2013. http://stakeholders.ofcom.org.uk/market-dataresearch/market-data/tv-sector-data/tvaccess-services-reports/access-q1q2-

Okyayuz, A. Ş. \& Kaya, M. (2017). Görsel-işitsel çeviri eğitimi. Ankara: Siyasal Kitabevi.

Okyayuz, A. Ş. (2019a). Görsel-işitsel çeviri ve engelsiz erişim. Ankara: Siyasal Kitabevi.

Okyayuz, A. Ş. (2019b). Ayrıntılı altyazı çevirisi. Ankara: Siyasal Kitabevi.

Paivio, A. ve Lambert, W. (1981). Dual coding and bilingual memory. Journal of Verbal Learning and Verbal Behavior, 20(5), 532-539.

Paivio, A. 1991. Dual coding theory: Retrospect and current status. Canadian Journal of Psychology/Revue Canadienne De Psychologie, 45(3), 255.

Perego, E. (2016). Gains and losses of watching audio described films for sighted viewers. Target, 28(3), 424-444.

Powers, S., Gregory, S. ve Thoutenhoofd, E. (1998). The educational achievements of deaf children. Londra: DfEE.

Remael, A. (2007). Sampling subtitling for the deaf and hard of hearing in Europe. J.Diaz Cintas, P. Orero \& A. Remael (Ed.), Media for all: subtitling for the deaf, audio description and sign language (ss. 23-52). Amsterdam \& New York: Rodopi.

Romero-Fresco, P. (2009). More haste less speed: Edited verbatim respoken subtitles. Vigo International Journal of Applied Linguistics VIAL, 6, 109-133. http://webs.uvigo.es/vialjournal/pdf/Vial-2009-Article6.pdf

RTÜK. (2019a). Sağırların, işitme ve görme engellilerin görsel-işitsel medya hizmetlerine erişiminin iyileştirilmesi çalıştayı. RTÜK Radyo ve Televizyon Üst Kurulu. https://www.rtuk.gov.tr/assets/Galeri/Haberler/sagirlarin-isitme-vegorme-engellileringorsel-isitsel-medya-hizmetlerine-erisiminin-iyilestirilmesi-calistayisonuc-bildirisi.pdf 
Türkiye'de Sağır ve Iş̧itme Engelli Çocuklar için Ayrıntılı Altyazı Çevirisi Hakkında Bir Araştırma: Uygulamada Sadeleştirme

RTÜK. (2019b). Sağırların, işitme ve görme engellilerin yayın hizmetlerine erişiminin iyileştirilmesine ilişkin usul ve esaslar hakkında yönetmelik. Resmi Gazete (11 Ekim 2019). https://www.resmigazete.gov.tr/eskiler/2019/10/20191011-15.htm.

Scognamillo, G. (2014). Türk sinema tarihi. İstanbul: Kabalcı Yayıncılık.

SEBEDER (Sesli Betimleme Derneği). (2020). Hakkımızda. http://sebeder.org/Hakkimizda-3.html

Simpson. P. A., Harrison D. R. \& Stuart, A. (1992). The reading abilities of a population of hearingImpaired children. Journal of the British Association of Teachers of the Deaf, 16, 47-53.

Talavan, N. (2006). Using subtitles to enhance foreign language learning. Porta Linguarum, 6, 4152.

Verfaillie, K. \& d'Ydewalle, G. (1987). Modality preference and message comprehension in deaf youngsters watching TV. (Psychological Reports No. 70). Belçika: University of Leuven.

Zárate, S. (2008). Subtitling for deaf children on British television. The Sign Language Translator and Interpreter, 2(1), 15-34.

Zárate, S. (2010). Bridging the gap between deaf studies and AVT for deaf children. J. Díaz Cintas, A. Matamala \& J. Neves (Ed.), New insights into audiovisual translation and media accessibility (ss. 159-174). Amsterdam: Rodopi.

Zárate, S. \& Eliahoo, J. (2014). Word recognition and content comprehension of subtitles for television by deaf children. The Journal of Specialised Translation, 21, 133-152. 